[Regular Paper]

\title{
Hydrocracking of Polycyclic Aromatic Hydrocarbons Catalyzed by Three Nickel-supported Different Zeolite Catalysts
}

\author{
Hisaji Matsui ${ }^{11)}$, Kenji Akagil ${ }^{12)}$, Masakatsu Nomura ${ }^{(2) *}$, and Yusaku Sakata ${ }^{\dagger 3)}$ \\ 1) Research \& Development Center, Osaka Gas Co., Ltd., 8-19-9 Torishima, Konohana-ku, Osaka 554 \\ 12) Dept. of Applied Chemistry, Faculty of Engineering, Osaka University, 2-1 Yamada-oka, Suita, Osaka 565 \\ '3) Dept. of Applied Chemistry, Okayama University, 1-1-1 Tsushima-naka, Okayama 700
}

(Received June 12, 1995)

\begin{abstract}
Hydrocracking of phenanthrene and pyrene over three different types of Ni-loaded zeolite catalysts (ZSM-5, Mordenite, and Y-type) was performed. The reaction conditions were as follows: $350^{\circ} \mathrm{C}$, $70 \mathrm{~kg} / \mathrm{cm}^{2}\left(\mathrm{H}_{2}\right), 0,15,60 \mathrm{~min}$. The presulfided $\mathrm{Ni}-\mathrm{Mo}$ catalyst was also examined for comparison. Among the three zeolite catalysts, clear-cut differences in product distribution were observed. In the case of phenanthrene, the extent of cracking depended upon the pore size of the catalysts. When ZSM-5 catalyst was used, a predominant production of dihydro-, tetrahydro- and sym- and unsymoctahydrophenanthrenes took place because phenanthrene could not enter the channel pores of these catalysts. In the case of $\mathrm{Y}$-type zeolite and mordenite, hydrocracking of phenanthrene skeleton proceeded more efficiently. The presulfided Ni-Mo catalyst was observed to be excellent for hydrogenating these polyaromatic compounds, but no cracking reaction was observed. In the case of using pyrene as a substrate whose molecular size is larger than the pore size of the channels of the zeolites employed, similar effects of pore size on product distribution were observed. Combination of the presulfided Ni-Mo catalyst and $\mathrm{Y}$-type zeolite was examined to obtain high yields of mono- and diaromatic compounds from pyrene, and the results observed were briefly discussed.
\end{abstract}

\section{Introduction}

The coal tar obtained from coal carbonization is a treasure trove of polyaromatic hydrocarbons, in which more than 400 kinds of aromatic compounds are found ${ }^{1)}$. Naphthalene, whose yield is about $9.0 \%$, is used for production of phthalic anhydride, dyestuff, pharmaceutical products and synthetic resins. On the other hand, the utilization of phenanthrene and pyrene, whose yields are $5.0 \%$ and $2.1 \%$, respectively, has so far been limited to production of carbon black and antiseptics of timbers.

The application of these aromatic compounds for starting materials of fine chemicals is not yet developed extensively. To develop new catalysts capable of converting ultimate three or four ring aromatics into mono- or di-aromatic compounds is one of the objectives of polyaromatics utilization. Hydrocracking of polyaromatic compounds appears to proceed via the formation of terminalnaphthenic ring of the starting aromatic compounds, followed by the cleavage of the naph-

\footnotetext{
* To whom correspondence should be addressed.
}

thenic ring to produce alkylated aromatic compounds, which have less number of rings than the starting aromatics. Accordingly, hydrogenation of aromatic rings and cracking of the resulting naphthenic rings are the key steps in hydrocracking, thus such dual-functional catalysts as metalsupported acid ones are considered to be some of the best candidates ${ }^{2) \sim 12}$.

In a previous paper ${ }^{13)}$, we conducted hydrocracking of phenanthrene over $\mathrm{H}-\mathrm{Y}, \mathrm{La}-\mathrm{Y}, \mathrm{Fe}-\mathrm{Y}$, and $\mathrm{Ni}-\mathrm{Y}$ zeolite catalysts and found that $\mathrm{Ni}-\mathrm{Y}$ zeolite catalyst showed the highest activity among the catalysts employed $\left(400^{\circ} \mathrm{C}, 1 \mathrm{~h}\right.$, and $70 \mathrm{~kg} / \mathrm{cm}^{2}$ of $\mathrm{H}_{2}$ ). In the related paper ${ }^{14)}$, we introduced the results of our CAMD study on product distribution of the liquid products from hydrocracking of phenanthrene and pyrene on Ni-loaded ZSM-5, mordenite, and Y-type zeolite catalysts. The present paper deals with the effects of the variables on the extent of hydrocracking of phenanthrene and pyrene using the above three catalysts, followed by detailed analysis of the products consisting of gaseous and liquid products and coke. The mechanism of this hydrocracking reaction is also considered. 


\section{Experimental}

\section{1. Preparation of Nickel-supported Zeolites}

Each of the three kinds of $\mathrm{NH}_{4}$-substituted zeolites $(50 \mathrm{~g})$ was stirred in $1000 \mathrm{ml}$ of aqueous solution of $\mathrm{Ni}\left(\mathrm{NO}_{3}\right)_{2}(0.25 \mathrm{M})$, at $90^{\circ} \mathrm{C}$ for $96 \mathrm{~h}$, then filtered and dried at $110^{\circ} \mathrm{C}$ to obtain a nickel cation substituted zeolite. The catalyst was calcined in a stream of air at $500^{\circ} \mathrm{C}$ for $4 \mathrm{~h}$, then reduced with $\mathrm{H}_{2}$ atmosphere at $450^{\circ} \mathrm{C}$ for $1 \mathrm{~h}$. The content of nickel in the zeolite was determined using a Rigaku Denki System 3270 type fluorescence X-ray analyzer. The distribution of acid sites in the catalyst was measured by using the temperature programmed $\mathrm{NH}_{3}$ desorption technique: catalyst was first, dried at $600^{\circ} \mathrm{C}$, then treated in a stream of $\mathrm{NH}_{3}$ at $110^{\circ} \mathrm{C}$ to absorb $\mathrm{NH}_{3}$ on the catalysts. The catalyst thus treated was cooled to $50^{\circ} \mathrm{C}$, then heated to $610^{\circ} \mathrm{C}$ with the rate of $4^{\circ} \mathrm{C} / \mathrm{min}$ in He atmosphere. The amount of $\mathrm{NH}_{3}$ desorbed was quantitatively analyzed by gas chromatography.

\section{2. Hydrocracking of Polyaromatic Hydrocar- bons}

Polyaromatic hydrocarbon ( $1 \mathrm{~g}$ ) and the nickelsupported zeolite catalyst $(0.5 \mathrm{~g})$ were placed in a $70 \mathrm{~m} l$ SUS 316 autoclave, which was pressurized to $70 \mathrm{~kg} / \mathrm{cm}^{2}$ with hydrogen and heated up to about $350^{\circ} \mathrm{C}$ at a rate of $8^{\circ} \mathrm{C} / \mathrm{min}$. Reaction time here means the duration of reaction at $350^{\circ} \mathrm{C}$. Therefore, $0 \mathrm{~min}$ of reaction time is with the run where the autoclave was taken out of the furnace and quenched to room temperature with an air blast. After the gaseous product was collected, its aliquot was submitted to GC analysis with a Shimadzu GC-3BT (active carbon column, $2 \mathrm{~m}$ ) and a Shimadzu GC-8AIT (silica gel column, 60/80 mesh, $3 \mathrm{~m}$ ). The liquid product was recovered by washing inside of the autoclave with $\mathrm{CH}_{2} \mathrm{Cl}_{2}$. According to the analysis by a JEOL JMS-DX-303HF type GC-MS and/or according to the reported results of analysis of anthracene oil ${ }^{15)}$, and the components of the liquid product were assigned by quantitative analysis conducted with a Shimadzu GC-14APFSC (CBP-1 capillary column, $0.5 \mathrm{~mm}$ (dia.) $\times 25 \mathrm{~m}$ ). The carbon deposited on the catalyst was evaluated based on the microanalysis of the recovered catalyst.

\section{Results and Discussion}

3. 1. Characterization of Nickel-supported Zeolites

The contents of nickel in Y-type zeolite $(8 \AA)$, mordenite $(7 \AA)$, and ZSM-5 type zeolite ( $5.5 \AA)$, based on the measurements by X-ray fluores-

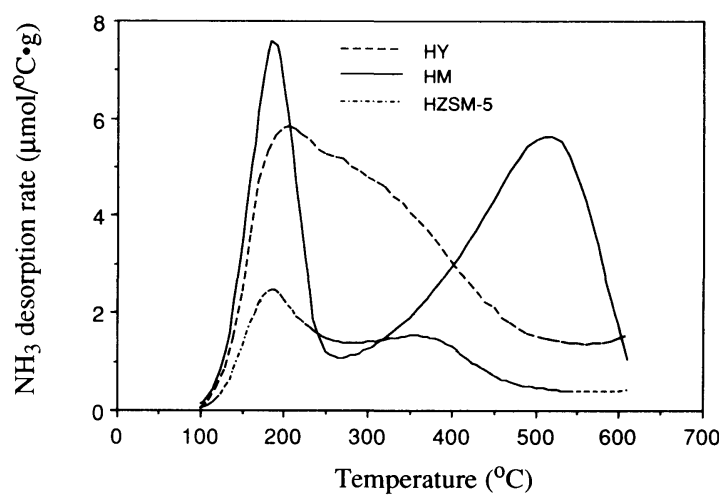

Fig. 1 NI $\mathrm{N}_{3}$-TPD Profile for Three Zeolite Catalysts

cence, were found to be $3.11,1.77$, and $1.22 \mathrm{wt} \%$ respectively. The number in parentheses indicates the pore diameter of zeolite channel. The results suggest that the larger the size of the pore is, the higher is the concentration of nickel on the catalyst when similar preparative methods for the zeolites were used.

The temperature profile of $\mathrm{NH}_{3}$-TPD is shown in Fig. 1. It is well known that TPD profiles of protonated zeolites show two maximum curves at around $200^{\circ} \mathrm{C}$ and in the range of $400-500^{\circ} \mathrm{C}^{16)}$, respectively, indicating that zeolite has two different types of acid sites ${ }^{16)}$. From such observations, the amount of acid sites in these zeolites follows the order: ZSM-5 $<$ mordenite $<$ Y-type.

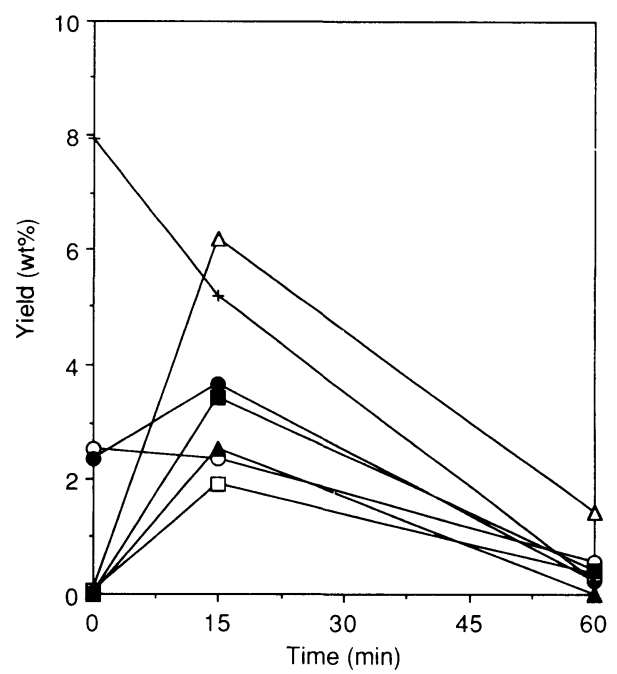

9,10-dihydro- (O), 1,2,3,4-tetrahydro- (O), sym-octahydrophenanthrenes $(\square)$, alkylated benzindans $(\square)$, alkylated tetrahydrobenzindans $(\Delta)$, sym-octahydroanthracene $(\boldsymbol{\Delta})$, and alkylated phenanthrenes $(+)$.

Fig. 2 Time Profile of Yield of Hydrogenated and Isomerized Phenanthrenes 
Table 1 Results of Hydrocracking for Phenanthrene

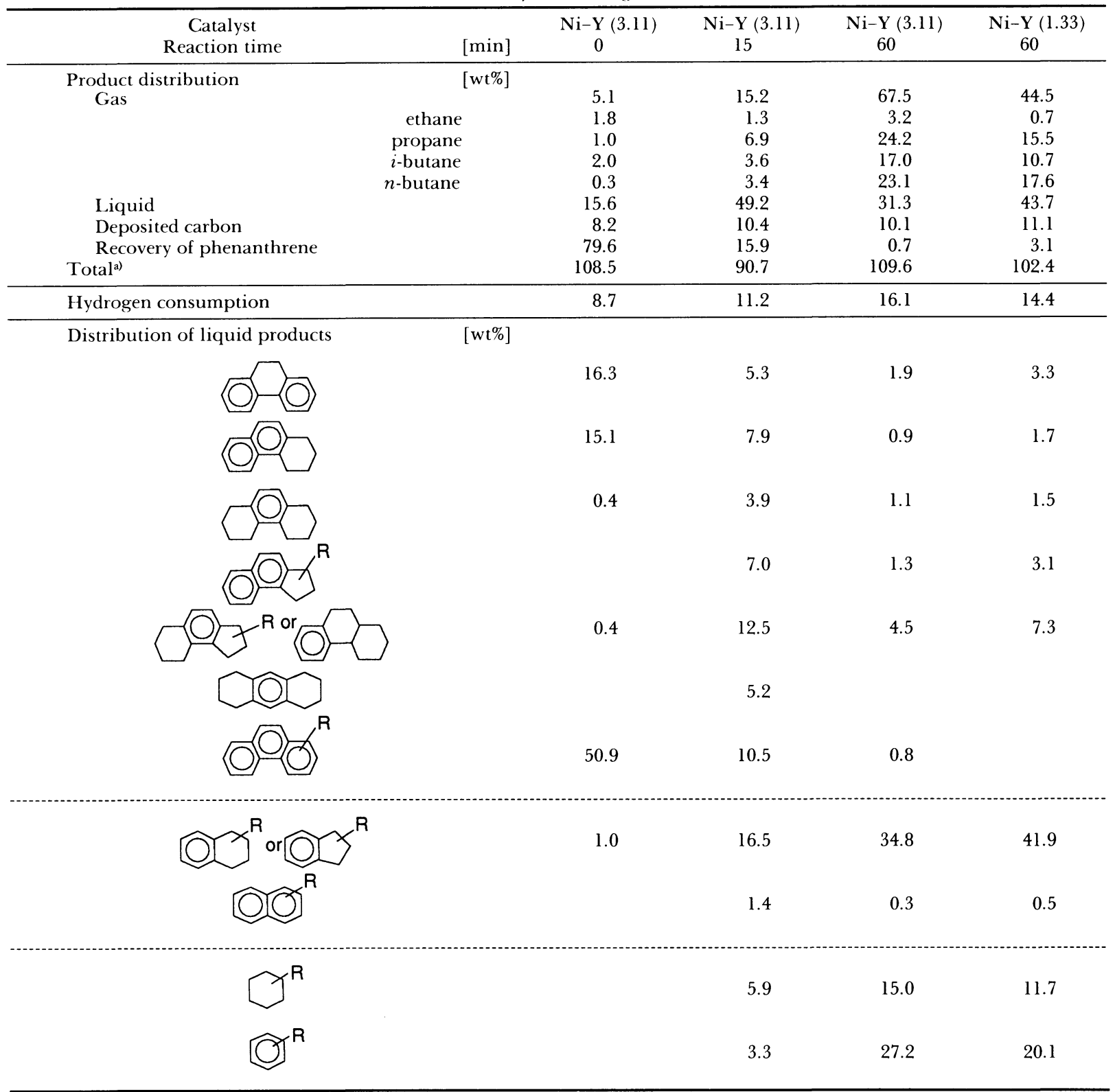

a) Total means the sum of wt\% of each fraction (liquids, deposited carbons, phenanthrene recovered, and gaseous products). Each fraction has specific error involved in its measurement so normalization to $100 \%$ was not used.

Strengths of the acid sites also follow the above order. Ni-Loaded catalysts also showed such TPD profile as cited above, and the amount of acid sites was found to show an increasing tendency compared with that of the corresponding protonated zeolites.

\section{2. Hydrocracking of Phenanthrene}

Hydrocracking of phenanthrene over the nickelsupported Y-type zeolite was conducted at $350^{\circ} \mathrm{C}$. By changing the time of reaction 0,15 and $60 \mathrm{~min}$, the recovery of phenanthrene was found to decrease in the order of 80,16 , and $0.7 \%$, respectively (Table $\mathbf{1}$ ). The gaseous products in- creased in the following order, $5.1 \%(0 \mathrm{~min}), 15.2 \%$ ( $15 \mathrm{~min})$, and $67.5 \%$ (60 min). Plots of the yields of products against reaction time (Fig. 2 based on data of Table 1) indicated that, when the reaction time was $0 \mathrm{~min}, 9,10$-dihydro- and 1,2,3,4-tetrahydrophenanthrenes were produced first, before they were isomerized to five membered saturate rings and skeletally isomerized to sym-octahydroanthracene along with the formation of symoctahydrophentanthrene. These compounds decreased after $60 \mathrm{~min}$ of reaction due to cracking. After 60 min of reaction, propane, $n$-butane, and $i$-butane became the main gaseous products, in- 
Table 2 Results of Hydrocracking for Phenanthrene

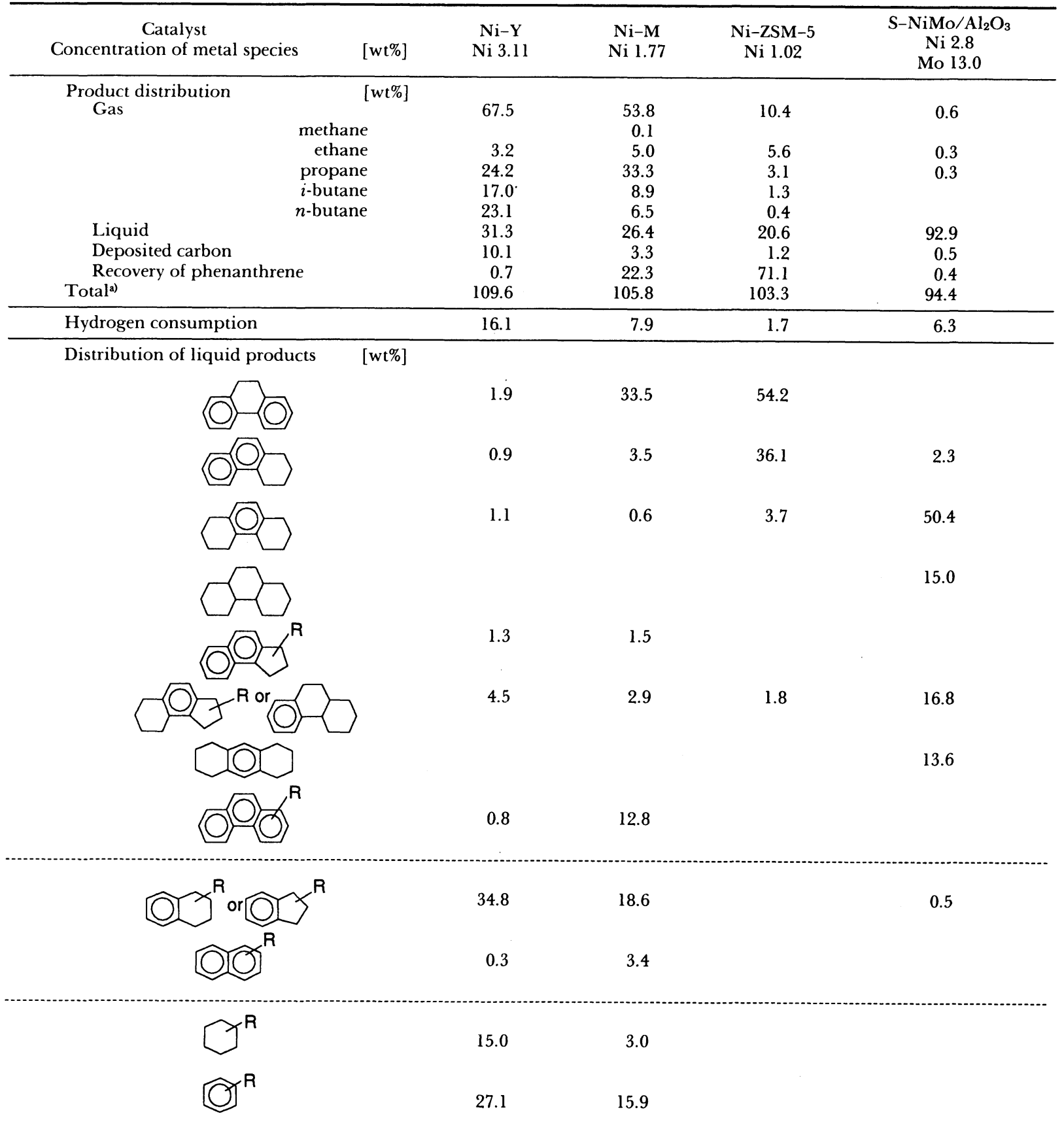

a) Total means the sum of wt\% of each fraction (liquids, deposited carbons, phenanthrene recovered, and gaseous products). Each fraction has specific error involved in its measurement so normalization to $100 \%$ was not used.

dicating that dealkylation reaction had extensively occurred, from $15 \mathrm{~min}$ - to $60 \mathrm{~min}$-reaction. Oneand two-ring compounds produced were benzene, cyclohexane, tetralin, and indan, along with their alkylated derivatives. At $0 \mathrm{~min}$ of reaction, a considerable amount of alkylphenanthrenes was observed; this was probably formed via transalkylation between alkylnaphthalene and phenanthrene.

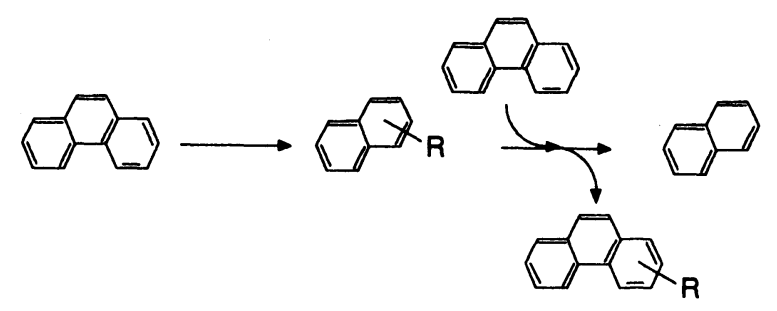

The results of hydrocracking of phenanthrene 
using nickel-supported ZSM-5, mordenite and Ytype zeolites are summarized in Table 2 that shows that catalytic activity of these zeolites increases according to the following order: ZSM-5 (29\%)< mordenite $(77.7 \%)<\mathrm{Y}$-type $(99.3 \%)$. The number in parentheses indicates the conversion of phenanthrene by hydrocracking. This order agrees well with the increasing order of pore size. Since the size of phenanthrene molecule is reported to be $7.9 \AA$, it may not be able to enter the channel of neither mordenite nor ZSM-5 type zeolite. On this point, we have conducted simulated diffusion of phenanthrene molecule into the mordenite channel by using the Computer-Aided Molecular Design (CAMD) technique ${ }^{14)}$. The results indicated that phenanthrene molecule could manage to get into the mordenite channel. Therefore, the reaction using $\mathrm{ZSM}-5$ type zeolite might proceed at outer acid sites. On the other hand, in the case of mordenite and Y-type zeolite, the substrate could enter the channel so that the reaction could proceed effectively to smaller products such as tetralins, indans, and benzenes, in addition to gaseous products. It should be noted that, in the case of mordenite, the yield of 9,10-dihydrophenanthrene was high and the yields of cyclohexane derivatives were small compared with those with Y-type zeolite. In the case of using protonated $\mathrm{Y}$ type catalyst, $70 \%$ of phenanthrene was observed along with $6 \%$ yield of dihydro- and tetrahydrophenanthrenes and $7 \%$ yield of alkylated phenanthrenes, while the yield of gaseous products was less than $5 \%$. These findings in conjunction with the product distribution with Ni-loaded Ytype zeolite clearly indicated that the acid sites in zeolite catalysts did crack hydroaromatic compounds that were supplied by hydrogenation of phenanthrene with the nickel species in the channel of the zeolite.

In the case of using presulfided nickel-molybdenum catalyst $\left(\mathrm{S}-\mathrm{NiMo} / \mathrm{Al}_{2} \mathrm{O}_{3}\right)$, which is often used for upgrading heavy oils, the conversion of the substrate reached $99.6 \%$, and the major products were hydrogenated phenanthrene, anthracene, and benzindan derivatives, and the yields of symoctahydro- and perhydrophenanthrene were $50.4 \%$ and $15 \%$, respectively. The above observations indicated that this catalyst, however, did not have the cracking capability.

Other factors affecting the conversion rate of the substrate and distribution of the products are the amount and/or the strengths of the acid sites and the amount of nickel metal in the zeolite. They were increased in the order: ZSM$5<$ mordenite $<Y$-type. This order is similar to that of the size of the zeolite channels as described in the section on the characterization of catalysts. These observations suggest that the highest activity of $\mathrm{Ni}-\mathrm{Y}$ catalyst corresponds not only to the size of the channel but also to the number of acid sites and to the concentration of nickel species.

Distribution of liquid products (in Table 2) clearly indicated that with runs using ZSM-5 (the smallest pore size), the main products were 9,10dihydro-, 1,2,3,4-tetrahydro-, and sym-octahydrophenanthrene derivatives along with their isomers (5 membered ring compounds). 9,10- and 1,2,3,4Positions of phenanthrene can approach the mouth of the channels of ZSM-5 type zeolite, and can take up the hydrogen atoms activated in the channel of the catalyst. Isomerization of naphthenic ring to 5-membered ring seems to take place in the channel of mordenite and Y-type zeolite because this isomerized product can hardly be observed with the ZSM-5 type zeolite. Dihydro-, tetrahydro-, and octahydro-derivatives are not the major products in the case of Y-type zeolite, because they are converted to benzene and cyclohexane derivatives. This difference may not be certain; however, in the mordenite, the same phenomenon takes place except that dihydroderivative is the main product. These findings clearly suggest that the skeleton of phenanthrene can enter the channel of mordenite and Y-type zeolite as suggested by CAMD study.

To search for the reaction conditions that could suppress the yield of gaseous products but produce mono- and diaromatic compounds in high yields, the following experiments were carried out. First, high loading of nickel seemed to give high yield of gaseous products: it was found that decrease in the amount of nickel loaded in Y-type zeolite $(1.33 \mathrm{wt} \%)$ resulted in the production of $43.7 \%$ liquid product (at $350^{\circ} \mathrm{C}$ for $60 \mathrm{~min}$ ), which composed of $42 \%$ of tetralins and indans, $20 \%$ of benzenes, and $12 \%$ of cyclohexanes (based on the yield of liquid products). In the case of using benzene as a solvent, the yield of liquid products was $45.4 \%$ and the yields of tetralins and indans, benzenes, and cyclohexanes were 47.8, 24.4, and $11.0 \%$, respectively. The reaction at $325^{\circ} \mathrm{C}$ for $60 \mathrm{~min}$ yielded $49.6 \%$ of liquid products, which contained $42.1 \%$ of tetralins and indans, $11.1 \%$ of benzenes, and $8.7 \%$ of cyclohexanes. Second calcium co-loading was considered to increase the cracking ability of nickel-loaded catalysts ${ }^{17)}$, 18), so the run was conducted with a co-loaded (with $0.37 \mathrm{wt} \%$ of nickel and $2.37 \mathrm{wt} \%$ of calcium) Y-type zeolite with which $59.5 \%$ of liquid products could be obtained, and three ring compounds became the main products. These results suggest that it is still difficult to design a reaction capable of 
producing mono- and diaromatic hydrocarbons selectively by mere changing of reaction conditions.

\section{3. Pyrene Hydrocracking}

In a preceding chapter, it was pointed out that hydrocracking of phenanthrene greatly depended on the pore size of the zeolite. Pyrene's molecular size is $9 \AA$; therefore, this molecule cannot enter the channel of Y-type zeolite. Since it would be interesting to investigate pyrene cracking with various types of zeolites, the three zeolites were used at $350^{\circ} \mathrm{C}$ for 0 and $60 \mathrm{~min}$ period. Figure 3 shows the time profile of the yields of the products using Y-type zeolite. At 0 min of reaction time, 4,5dihydropyrene was obtained as the main product together with two kinds of hexahydropyrenes. In this case, it is interesting to note that $1,2,3,6,7,8$ hexahydropyrene was preferred to other isomer and dihydro derivatives, which suggested that 1,2,3-positions of pyrene could approach with ease the channel of Y-zeolite. On the other hand, yields of 4,5,9,10-tetrahydro derivatives were similar to those of two kinds of decahydro-derivatives and perhydro-derivatives, suggesting that production of these kinds of compounds was not preferable because of the steric hindrance between the substrate and the mouth of zeolite channel. As reaction proceeded, the yields of smaller compounds such as one- and two-ring compounds increased significantly while three ring aromatic compounds increased monotonically.

Table 3 shows the results of reaction at $350^{\circ} \mathrm{C}$ for $60 \mathrm{~min}$ using the three zeolites. The conversion rate of pyrene increased in the order: $\mathrm{Ni}-\mathrm{ZSM}$ $5<\mathrm{Ni}$-mordenite $<\mathrm{Ni}-\mathrm{Y}$. In the case of using $\mathrm{Ni}-\mathrm{ZSM}-5$, a yield of $22.7 \%$ of liquid products was obtained, but they were mostly hydrogenated pyrene. With the Ni-loaded mordenite, the yield of liquid products reached $46.1 \%$; however, they contained hydrogenated pyrene as the main product. On the other hand, a yield of $15.3 \%$ of smaller compounds such as hexahydro- and dihydrophenarene, acenaphthene, and benzindan was obtained by using Ni-loaded Y-type catalyst. Dihydro-, tetrahydro-, and two kinds of decahydropyrenes were obtained as major products by using the Ni-loaded ZSM-5 type catalyst.

3. 4. Combination Use of Two Different Catalysts to Enhance Yields of Mono- and Diaromatics

Presulfided Ni-Mo catalyst was found very effective for hydrogenation of phenanthrene and pyrene, while Ni-loaded Y-type zeolite was most effective for hydrocracking among the three zeolites. We assumed that partial hydrogenation of polyaromatics over the Ni-Mo catalyst followed

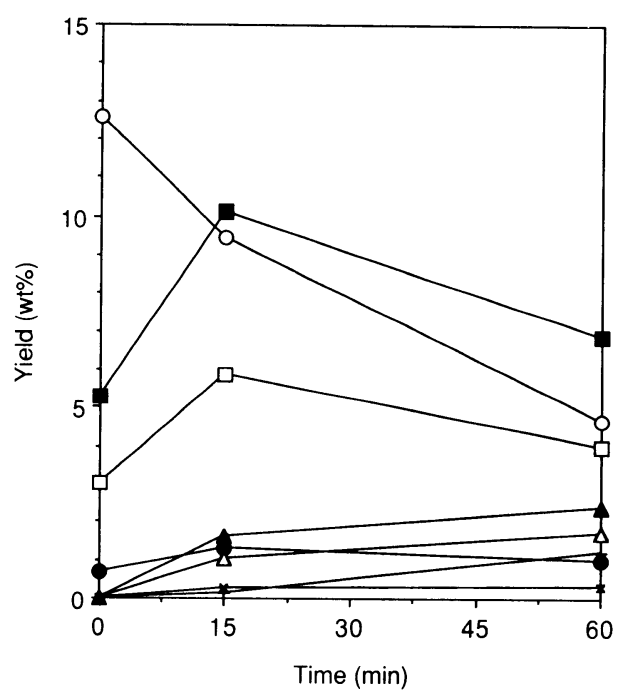

4,5-dihydro- (O), 4,5,9,10-tetrahydro- (O), 1,2,3,3a,4,5hexahydro- $(\square), 1,2,3,6,7,8$-hexahydro- $(\square), \quad 1,2,3,3 \mathrm{a}$, $4,5,9,10,10 \mathrm{a}, 10 \mathrm{~b}$-decahydro- $(\Delta), \quad 1,2,3,3 \mathrm{a}, 4,5,5 \mathrm{a}, 6,7,8$ decahydro- $(\boldsymbol{\Delta})$, perhydro- $(+)$, and alkylated pyrenes $(\times)$.

Fig. 3 Time Profile of Production of Hydrogenated Pyrenes

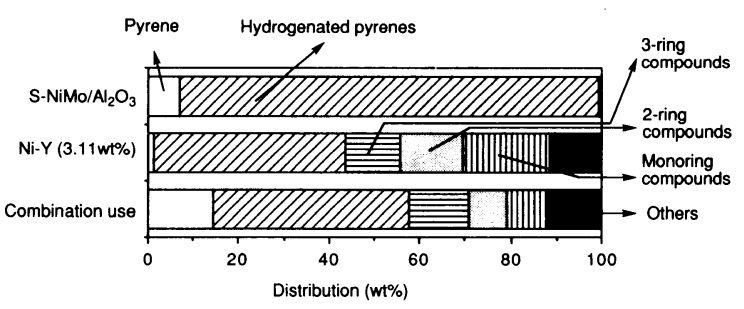

Fig. 4 Distribution of Liquid Products in Single- and Two-stage Hydrocracking Reaction of Pyrene

by cracking over the Ni-loaded $\mathrm{Y}$-type zeolite would exhibit the possibility of yielding more valuable mono- and di-aromatic compounds from pyrene. The results are shown in Fig. 4. As described in a previous chapter, neither one- nor two-ring compound was formed in the reaction using presulfided $\mathrm{NiMo} / \mathrm{Al}_{2} \mathrm{O}_{3}$ as catalyst, while the yields of one- and two-ring compounds in the liquid products were $18.8 \%$ and $14.0 \%$ for $\mathrm{Ni}-\mathrm{Y}$, and $8.7 \mathrm{wt} \%$ and $8.3 \mathrm{wt} \%$ for the combined presulfided $\mathrm{NiMo} / \mathrm{Al}_{2} \mathrm{O}_{3}$ and $\mathrm{Ni}-\mathrm{Y}$ catalyst, respectively. From these results, it seems difficult to increase the yields of mono- and di-aromatic compounds by use of a combination of two different catalysts for hydrogenation and cracking. 
Table 3 The Results of Hydrocracking Reaction of Pyrene by Using Nickel-loaded Zeolites

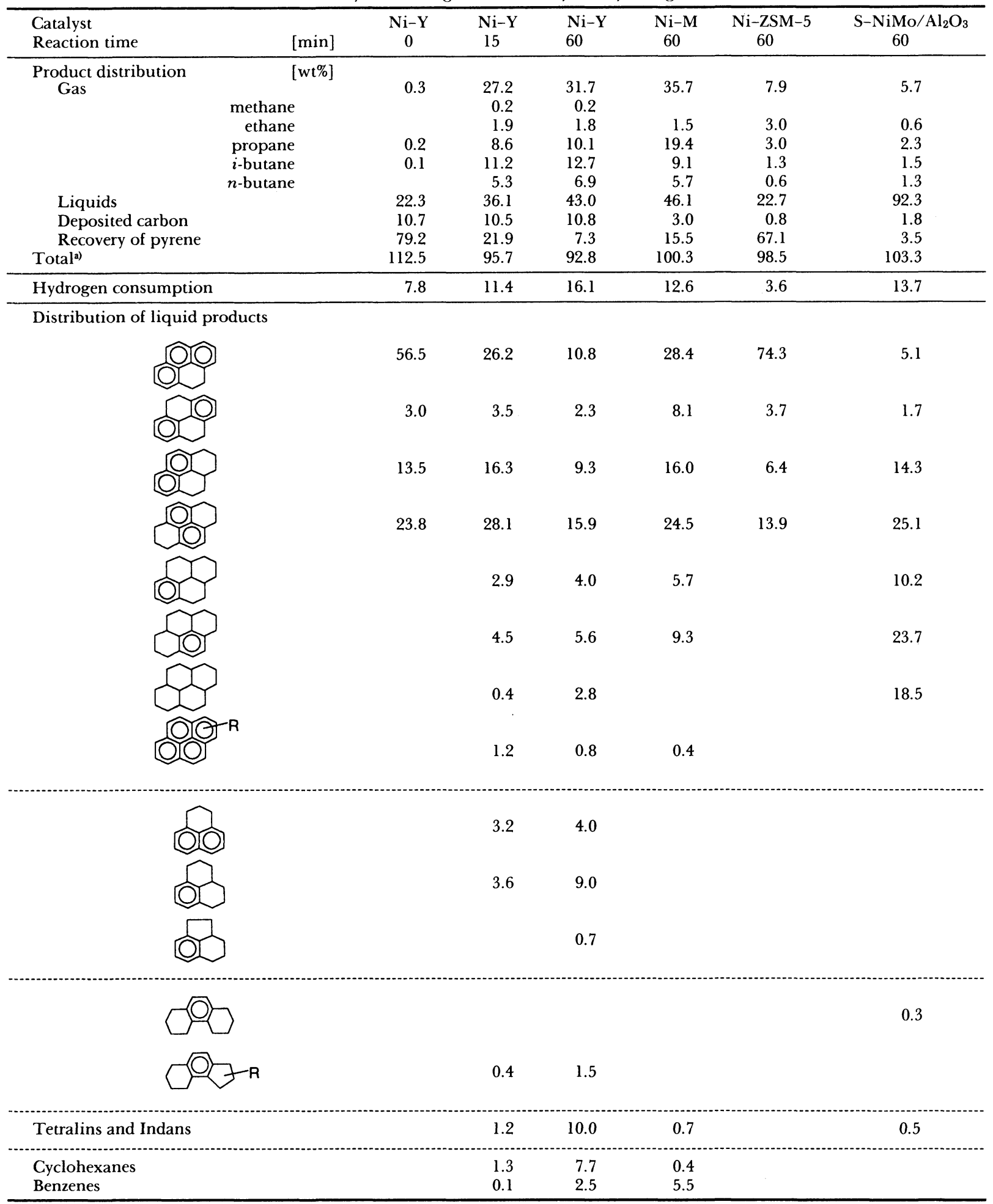

a) Total means the sum of wt\% of each fraction (liquids, deposited carbons, pyrene recovered, and gaseous products). Each fraction has specific error involved in each measurement so normalization to $100 \%$ was not used.

\section{Conclusion}

To develop a reaction for conversion of poly- aromatics such as phenanthrene and pyrene to mono- and di-aromatic compounds, hydrocracking reaction was conducted by using the three different nickel-loaded zeolite catalysts at $350^{\circ} \mathrm{C}$ 
and for about $1 \mathrm{~h}$. Nickel-loaded Y-type catalyst showed the highest activity among the three zeolite catalysts employed, and almost all phenanthrene was converted. In the case of using Ni-ZSM-5 catalyst which has a smaller pore size of channel compared with that of Y-type zeolite catalyst, the conversion of the substrate decreased substantially, but no mono- and di-aromatics were observed. Based on the channel size of mordenite $(7 \AA)$ and that of phenanthrene $(7.9 \AA)$, phenanthrene would probably not be able to enter the channel of mordenite; however, the study on diffusion of phenanthrene on mordenite by CAMD technique revealed that the molecule could manage to get into its channel. The fact that product distribution with Ni-mordenite is similar to that with $\mathrm{Ni}$ Y-type zeolite, except for some minor differences, is in good agreement with the results of the CAMD study. These results clearly indicate that the pore size of the zeolite channel should be one of the most important factors that determine the degree of hydrocracking of phenanthrene. When pyrene was used as a substrate, a similar tendency of size of the channel influencing the product distribution was observed. Therefore, the conversion of the substrate and the yields of much smaller ring compounds decreased compared with those in the case of phenanthrene. These results indicate that product distribution in hydrocracking of polyaromatic compounds can be evaluated adequately in terms of the relationship between the molecular size of polyaromatics and the pore size of the zeolite catalyst channel.

\section{References}

1) Kurata, N., Kagaku to Kogyo, 41, 147 (1988).

2) Wiser, W. H., Singh, S., Qader, S. A., Hill, G. R., Ind. Eng. Chem., Prod. Res. Dev., 9, 350 (1970).

3) Haynes Jr., H. W., Ind. Eng. Chem., Process Des. Dev., 22, 401 (1983).

4) Constant, W. D., Price, G. L., McLaughlin, E., Fuel, 65, 8 (1986).

5) Lapinas, A. T., Klein, M. T., Gates, B. C., Macris, A., Lyons, J. E., Ind. Eng. Chem. Res., 26, 1026 (1987).

6) Lapinas, A. T., Klein, M. T., Gates, B. C., Macris, A., Lyons, J. E., Ind. Eng. Chem. Res., 30, 42 (199l).

7) Russell, C. L., Klein, M. T., Quann, R. J., Trewella, J., Energy Fuels, 8, 1394 (1994).

8) Corna, A., Miguel, P. J., Orchilles, A. V., Koermer, G. S., J. Catal., 135, 45 (1992).

9) Guerzoni, F. N., Abbot, J., J. Catal., 139, 289 (1993).

10) Townsend, A. T., Abbot, J., Energy Fuels, 8, 690 (1994).

11) Townsend, A. T., Abbot, J., Fuel Process. Technol., 37, 271 (1994).

12) Dossi, C., Psaro, R., Ugo, R., Conrad Zhang, Z., Sachtler, W. M. H., J. Catal., 149, 92 (1994).

13) Ueda, K., Matsui, H., Song, C., Sekiyu Gakkaishi, 33, (6), 413 (1990).

14) Matsui, H., Akagi, K., Murata, S., Nomura, M., Energy Fuels, 9, 435 (1995)

15) Miki, Y., Sugimoto, Y., Nihon Kagaku Kaishi, 1983, 704.

16) Sato, H., Hirose, K., Kitamura, M., Nihon Kagaku Kaishi, 1989, 1550.

17) Richardson, J. T., J. Catal., 21, 122 (1971).

18) Shil, L. N., Bhatla, S., Ind. Eng. Chem., Prod. Res. Dev., 25, 530 (1986). 
要 旨

\section{3 種のニッケル担持ゼオライト触媒を用いる多環芳香族化合物の水素化分解反応}

松井 久次 ${ }^{+1)}$, 赤木 健二十2), 野村 正勝 ${ }^{\dagger 2)}$, 阪田 祐作 $^{\dagger 3)}$

†1) 大阪ガス (株) 開発研究所, 554 大阪市此花区酉島 8-19-9

+2) 大阪大学工学部応用化学科, 565 大阪府吹田市山田丘 2-1

+3) 岡山大学工学部精密応用化学科, 700 岡山市津島中 1-1-1

細孔径の異なる 3 種のニッケル担持ゼオライト（ZSM-5 型, モルデナイト，Y型せオライト）を触媒に用いたフェナント レン㧍よびピレンの承菜化分解反応を $350^{\circ} \mathrm{C}, 70 \mathrm{~kg} / \mathrm{cm}^{2}$ の水 素加圧下で，0，15，分行った。また，比較のため予備硫化 した $\mathrm{Ni}-\mathrm{Mo} / \mathrm{Al}_{2} \mathrm{O}_{3}$ 触桇を用いた反応についても検討を行っ た。用いたゼオライト触媒により生成物分布は大きく変化する ことが明らかとなった。フェナントレンを基質とした場合，ク ラッキング生成物収率はゼオライト触媒の細孔径に依存し, 細 孔径の小さいてSMーbさみライトを触媒とした場合，ジヒドロ フェナントレン, テトシヒドロフェナントレン，オクタヒドロ フェナントレンの生成が優先した。これは，フェナントレン分 子がこのゼオライト触媒の細孔内へ侵入できないためと考えら
れる。一方, Y 型ゼオライト㧍よびモルデナイトを用いた場合, フェナントレン骨格の分解が効果的に進行し, プロパン, ブタ ン, ベンゼン類，インダン類が主生成物となった。 $\mathrm{Ni}-\mathrm{Mo} / \mathrm{Al}_{2} \mathrm{O}_{3}$ 触媒を用いた場合, 基質の水素化が優先し, 分 解反応はほとんど進行しなかった。分子サイズが大きく， 3 種 のゼオライト細孔内に侵入できないピレンを基質とした場合は 部分水素化物が優先して生成する傾向が観測された。また, 単 環, 二環化合物への選択的分解を目的として水素化能の高い $\mathrm{Ni}-\mathrm{Mo} / \mathrm{Al}_{2} \mathrm{O}_{3}$ 触媒とクラッキング能の高い $\mathrm{Ni}$ 担持 $\mathrm{Y}$ 型ゼオ ライトを組み合わせた 2 段階水素化分解についても検討を 行った。

\section{Keywords}

. Zeolite, Hydrocracking, Polycyclic aromatics, Nickel, Pore size, Product distribution 